\title{
Strategic manufacturing - requirements for supporting tool
}

\author{
Jaroslaw Chrobot, Tomasz Sobczyk and Marcin Walczak \\ Institute of Production Engineering and Automation, Centre for Advanced Manufacturing \\ Technology, Wroclaw University of Technology, Poland
}

\begin{abstract}
In the time of increasing global competition and establishing short product life time cycles phenomenon, activity of industrial companies is subject to significant limitations. Hard or impossible becomes acting only on the local markets and investment in systems, which base on economics rules, exceed company abilities. Under such conditions, apart from properly determined strategy, more of importance becomes considering cooperation. In the paper framework of strategic manufacturing and cooperation between companies is presented as well as requirements for a supporting tool.
\end{abstract}

Keywords

Cooperation, strategy, manufacturing system, strategy supporting tool.

\section{INTRODUCTION}

Company strategy formulation is based on investigation regarding its internal abilities and its environment. In the aftermath of the investigation one can decide if the option of independent activity is possible or if it limits market chances of the company significantly. In the moment, when investigations point at the second solution, consideration of starting cooperation is suggested. Things can come to this situation for example, when investment in flexibility of manufacturing system will exceed its financial abilities or will be connected with a big risk.

Because the basic requirement for cooperation is its stability, this decision should be based on internal investigations of the both partners. In the article requirements for a system are mentioned, which can be applied to transform a general industrial company strategy to its functional strategy and design of manufacturing system. Therefore is possible to determine requirements for cooperation on the basis of detailed data, which regard market, products characteristics as well as manufacturing system. 


\section{COOPERATION - A STRATEGY VIEW}

The management of an organisation often requires the reconciliation of two contradictory tendencies. An enterprise acting in a turbulent environment must strive for the certain level of flexibility and adaptability on one hand, and consolidate its efforts in order to ensure effective operation on the other [Moszkowicz 1995]. From the practical point of view i.e. assuming the limited ability of an enterprise to gather strategically-related potential, the simultaneous accomplishment of both conflicting factors is not possible. The nature of a company is that day-to-day actions and operations are usually routine procedures, adoption to changing environment however, requires the steady changing of its structures. The search for a solution to this dilemma goes beyond the single enterprise and it is assumed that the company shall cooperate on the enterprise level.

\section{Forms of cooperation}

Cooperation of companies can be executed by different forms of activity connections in order to achieve the common goal (Figure 1). Assuming two division criteria: the level of cooperation and the extent to which changes in management are taking place, one can draw companies' collaboration map [Cygler 2002].

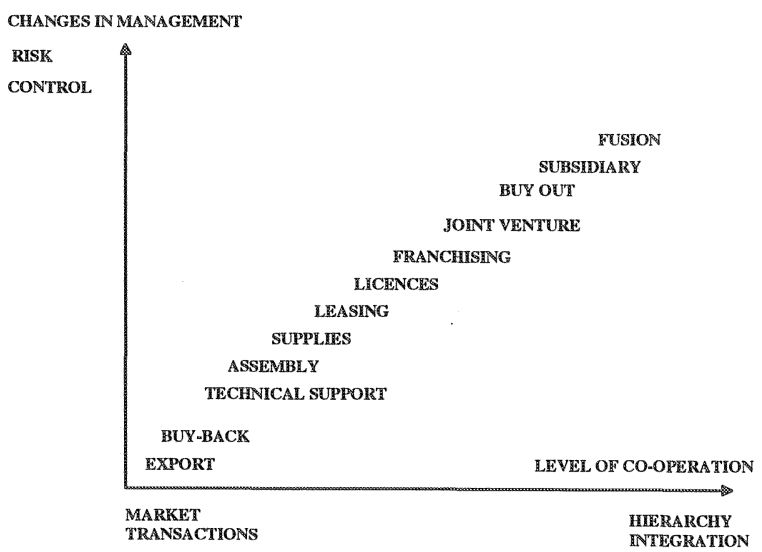

Figure 1-Different forms of collaboration [Cygler 2002]

Presented map provides an overview of how strong independent partners are interrelated and what is the scope of these connections. Export - the least risky activity that requires no transfer of resources, has been pointed out as a most casual form of cooperation. Moreover it seems to require only little changes in managerial tasks. In contrary, fusions have been regarded the most demanding form of cooperation in terms of integration of partners' resources. In between these two cooperation forms there are intermediate ones. They have a form of market transactions but also represent a capital and non-capital forms of business organisation. 
Among different forms of cooperation presented on the chart one can distinguish strategic alliances which can be viewed between licenses and companies bought out. Since more than $70 \%$ of cooperations in the recent years have been of this kind, it is worth looking at them closer [Strategor 1995].

\section{Strategic alliances}

Strategic alliances are defined as long-term and intentional agreements between the companies, reached on the basis of partnership and adequacy of present and future benefits, with the distinct organizational structures of involved parties [Cygler 2002]. The motivation for reaching the alliances are different and normally depend on the needs and expectations of partners involved as well as their position and market situation. The classification of motivation factors is listed in the table 1 .

Table 1 - The classification of motivation factors (based on [Cygler 2002])

\begin{tabular}{|c|c|}
\hline $\begin{array}{l}\text { Motivation } \\
\text { Classitication }\end{array}$ & Benelits \\
\hline Lowering the risk & $\begin{array}{l}\text { The risk of the project is to be spread over more partners. } \\
\text { Reinsurance activities of the insurance companies can be regarded as } \\
\text { the example to be followed; } \\
\text { Lowered project lead-time and hence decrease in a risk of } \\
\text { unfavorable changes in the environment; } \\
\text { Investment costs spread over more partners as well as cost } \\
\text { subadolivity - the unit cost (cost per partner) lower than the cost they } \\
\text { would have to be covered if they acted alone; } \\
\text { Product portfolio diversification; } \\
\text { Diversification of business locations }\end{array}$ \\
\hline $\begin{array}{l}\text { Stimulation of } \\
\text { competition }\end{array}$ & $\begin{array}{l}\text { Straightening the barriers for entering the market segment by means } \\
\text { of partner consolidation; } \\
\text { Market sector's structure rationalisation - the avoidance of fight } \\
\text { between competitors; } \\
\text { More straighten and stable competitive advantage of cooperating } \\
\text { partners; }\end{array}$ \\
\hline $\begin{array}{l}\text { Economies of } \\
\text { scale and } \\
\text { production } \\
\text { rationalisation }\end{array}$ & $\begin{array}{l}\text { Formation of optimal-size plants, } \\
\text { Balanced use of production capacities, } \\
\text { Standardization of quality aspects, dimensions, manufacturing forms } \\
\text { etc.; } \\
\text { Type unification - standardized usage of different forms of final } \\
\text { products, } \\
\text { Specialised production in plants - partner companies manufacture } \\
\text { only given parts or product types (in contradiction to the situation } \\
\text { where company produces all the required components), } \\
\text { Production portfolio diversification (diversified production as a } \\
\text { result of introduction of the new products to be manufactured) } \\
\text { More rational purchasing; }\end{array}$ \\
\hline
\end{tabular}




\begin{tabular}{|c|c|}
\hline $\begin{array}{l}\text { Technology and } \\
\text { complementary } \\
\text { patents exchange } \\
\text { (i.e. technology } \\
\text { transfer) }\end{array}$ & $\begin{array}{l}\text { Avoidance of research and development activities duplication; } \\
\text { Better chances for faster certification when partners come from } \\
\text { different countries (only when countries respect the certificates); } \\
\text { Ceding of properties and laws of unfinished production processes; } \\
\text { The share of experience and know-how between partners; } \\
\text { Synergy effect }\end{array}$ \\
\hline $\begin{array}{l}\text { Administration } \\
\text { barriers' } \\
\text { overcome }\end{array}$ & $\begin{array}{l}\text { The ability to overcome discriminating tax policies, property } \\
\text { turnover policies, tighten certification policies etc. }\end{array}$ \\
\hline $\begin{array}{l}\text { Facilitation of } \\
\text { expansion to } \\
\text { foreign markets to } \\
\text { inexperienced } \\
\text { partners }\end{array}$ & $\begin{array}{l}\text { Reduced expansion time to foreign markets; } \\
\text { Reduced costs and risk involved in foreign markets' expansion; }\end{array}$ \\
\hline $\begin{array}{l}\text { Competitive } \\
\text { advantage of } \\
\text { vertical quasi } \\
\text { integration }\end{array}$ & $\begin{array}{l}\text { Reduction in cooperation's transaction costs against chosen } \\
\text { integration variant. } \\
\text { Production and manufacturing programs integration; } \\
\text { Information, know-how, experience and patents exchange; } \\
\text { Establishing common research and development units; } \\
\text { Higher Return on Investment; } \\
\text { The ability to establishing joint distribution channels and taking } \\
\text { common marketing actions; }\end{array}$ \\
\hline Specific & $\begin{array}{l}\text { Taking advantage of differences between characteristics of } \\
\text { geographical locations of partners; } \\
\text { Geographical location and economical position } \\
\text { Favourable legislation differences } \\
\text { Tourist attractiveness } \\
\text { Ethnic relations and/or family relations }\end{array}$ \\
\hline
\end{tabular}

\section{STRATEGIC ALLIANCES AND COMPANY'S STRATEGY}

The motivation for reaching the alliance is usually correlated with strategic goals of the enterprises embarking on this kind of coalition. Due to the strategic character of the cooperation, agreements and decisions of what partner to choose and what kind of cooperation is to be established, are usually taken on the highest managerial level.

The way the alliance is executed affects also the enterprise's policy at the level of its individual units. Directions in which individual units develop the corporate strategy determine the goals of the strategic alliance regarding products and markets. This has been illustrated in the H.I. Ansoff's matrix in Figure 2.

The execution of competitive coalition entails that operations and functional strategies of all partners must be adjusted. Moreover, from the operational point of view, when it comes to assigning competences to each partner, flexible and effective logistic solutions are required. This aspect of the problem determines to the great extent how effective the collaboration will turn out to be. 


\begin{tabular}{|c|c|c|c|}
\hline & \multicolumn{2}{|r|}{ MARKETS } \\
\hline & & Present & New \\
\hline \multirow{2}{*}{ 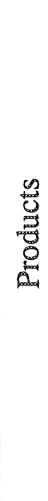 } & 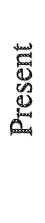 & $\begin{array}{l}\text { MARKET PENETRATION } \\
\text { - } \text { economies of scale } \\
\text { risk reduction } \\
\text { joint marketing }\end{array}$ & $\begin{array}{l}\text { MARKET DEVELOPMENT } \\
\text { - overcoming barriers of entry } \\
\text { reducing risk of being in business } \\
\text { joint marketing operations (mainly in the } \\
\text { area of distribution and sales activation) }\end{array}$ \\
\hline & $\frac{z}{2}$ & $\begin{array}{l}\text { PRODUCT DEVELOPMENT } \\
\text { new technologies } \\
\text { acquisition } \\
\text { new skills acquisition } \\
\text { joint marketing }\end{array}$ & $\begin{array}{l}\text { DIVERSIFICATION } \\
\text { knowledge transfer (learning from the } \\
\text { partner or joint knowledge acquisition), } \\
\text { risk reduction and minimising the costs } \\
\text { of entering new markets and sectors } \\
\text { economies of range }\end{array}$ \\
\hline
\end{tabular}

Figure 2 - The goals of strategic alliance depend on what product and market policy has been chosen (on the basis of H.I. Ansoff's matrix) [Cygler 2002]

\section{LOGISTICS SOLUTIONS - SUPPLY CHAINS}

Supply chain comes into being as a result of independent partners' alliance. Its objective is the cooperation of its participants in order to gain the advantage over the competitors. There is product, information and cash flow among participants in the chain.

The transparency regarding inventories hold and turned over in the whole chain plays the key role in the logistics chain management. The objective is not to move the inventory among collaborating partners but to carefully coordinate inventory levels in the whole chain. Reliable and detailed information flow amongst chain partners ensures that purchasing, production and inventory planning causes minimum stock. As a result costs can be reduced. Moreover, the system of mutual involvement of cooperating partners guarantees that long-term strategic plans can be worked out.

The modern approach to logistics chains assumes that one company from among collaborating partners is chosen to be a leader. The role is usually assigned to the strongest partner (i.e. one that is characterised for example by its economic strength, size and authority). The leader is responsible for the goals to be accomplished. The example of how leader can act has been presented on the Figure (Figure 3) below. 


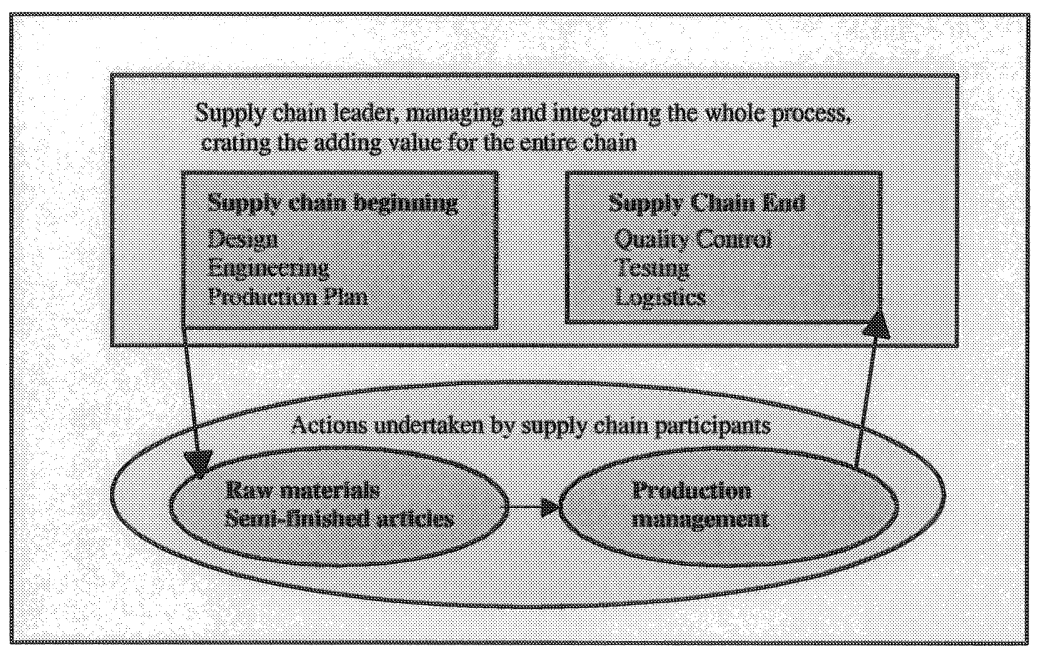

Figure 3 - Supply Chain Management. Adding-value by Supply Chain Leader [Christopher 1992]

The search for a suitable structure of supply chain shall is to take into account unstable and changing market requirements to build a system being flexible enough and able to react to market variables as fast as possible. It is due to the fact that market conditions challenge the former way of dealing with inventories which is based on replenishing required levels of stock. In the literature one can find future system solutions that are lent against specialised application tools. Among them one can distinguish Concurrent Logistics System (CLS).

\section{Concurrent logistics system}

Concurrent Logistics System (CLS) is a term developed by Gartner Group to name the future solutions concerning resources flow management in logistics chains. It is based on the network of interacting applications located in the appropriate nodes of the chain. The applications are event-driven e.g. customer purchase, order confirmation etc., and related to business processes spread over entire chain and not limited to the individual organisation or single business unit. The concept also assumes that IT systems used exclusively by logistics departments in the companies or by single plants are no longer effective enough. On the contrary, they should by exchanged by systems capable of working with different applications used by cooperating companies. This shall lead to the creation of Integrated Logistics Chain. The ability of each partner's application to be linked to the system and to operate in a networking mode (what should be not restricted only to those partners who represent the following nodes), leads to the more effective resources exchange and flow. This can be done, among others, by elimination of multiplication in information processing as well as improved cooperation of chain partners, what in turn leads to sudden raise in material turnover pace in the chain itself.

In the context of cooperation, apart from logistics integration, there is a problem of transforming alliance-related strategic decisions on the ground of individual strategies and manufacturing strategies of participating partners. Presented tool aids 
the process of establishing the range of collaboration on one hand, and enables efficient match of manufacturing calls and alliance requirements. Logistics actions to be carried out are considered in general on the strategy level and their detailed implications are incorporated in the implementation plans.

\section{HOW TO AID A PROCESS OF STRATEGY FORMULATION?}

It can be said that from the research carried out on manufacturing strategy so far, it has been not fully advised how companies shall transform strategic goals aiming at satisfying customer needs and expectations into necessary operational set of decisions. Moreover, the companies find it difficult to select the key decisions that would determine the success in satisfying the customer wants. Hence, although the company is fully concerned about the areas that would provide competitive edge, it is often unable to choose the right way to achieve this goal. In the other words, it is not always clear for the companies how to achieve competitive advantage by means of consistent mixture of customer needs, strategic objectives and appropriate operational decisions [Gilgeous 1999].

No matter how specific the manufacturing strategy, the key issue is that it must be consistent within the whole organization and with the chosen form of cooperation, and that the relevant decisions are supportive to this strategy. For example, when a company formulates its strategy and chooses as a order-winning factor the provision of the highest-quality goods, all the lower-level operational decisions (e.g. decisions regarding detailed design of manufacturing system and form of cooperation) must derive from the goals established on top managerial level. A good understanding of how changes in market environment transform into the need for change in manufacturing system and vice versa shall let the managers and engineers design manufacturing systems that will be ready to succeed in a turbulent market circumstances.

All the companies nowadays strive to raise quality of their products, shorten production lead-times, improve operational effectiveness, and reduce costs. Concentration on these factors may result in the improvement of many performance metrics. However, the success is only to be achieved when system's concept will reach beyond small operational improvements. The goal is to identify and improve processes in the much broader perspective. The decisions must be based on customer needs, enterprise's strategic goals and objectives that aim at establishing unique, long-lasting and permanent competitive advantage. This requirement must be addressed to all the coalition partners [Kaplan 2001].

In accordance with what has been said above and to support the companies with their decision making processes, there has been the project issued by the Polish State Committee for Scientific Research. The project scheduled for 3 years is carried out in the Centre for Advanced Manufacturing Technology located within Institute for Production Engineering and Automation of Wroclaw University of Technology, Poland. The major objective of the project is to build a prototype of computer-aided system for strategic manufacturing. 


\section{SYSTEM FOR STRATEGIC MANUFACTURING}

The basic goal of the presented system is to achieve such a state of manufacturing function and sustain the dynamics of its changes so that identified present and future customers needs are fulfilled by profitable production and sales of manufactured goods. The initial concept of the system is based on two activity loops (see Figure 4).

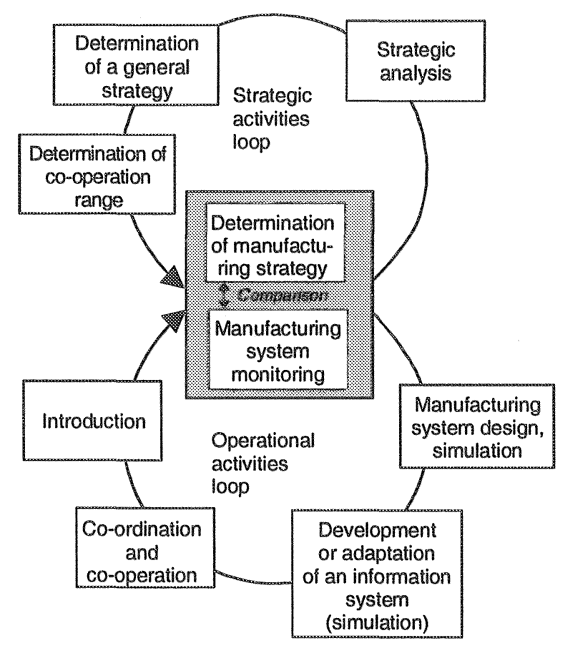

Figure 4 - Overview of Strategic Manufacturing

Strategic actions loop adapts the system to the present and future market requirements defined in a long-term perspective. In the other words the loop specifies present and far-reaching state of manufacturing function and range of cooperation - manufacturing strategy. Actions of the second loop are dedicated to the achievement of the assumed state of the manufacturing system. They aim at delivering solutions and appropriate operations and coordination with partners, so that relevant parameters representing system's state are consistent with manufacturing strategy.

The concept that has been briefly described above assumes four key levels of operation. On the level of strategic analyses, present and future market situation as well as current and forecasted customers' needs are determined. Products that are designed to accomplish the customer wants and to provide them expected value, have to be supported by adequate solutions on the shop-floor level. As a consequence of manufacturing function's adaptation actions, in the future threats and opportunities are likely to turn up. It is due to the fact that customers' needs and expectations vary over time, clients' perception of the product's value and usefulness changes, and the competition normally grows stronger. Hence, execution agenda approved at the given point of time can turn out to be insufficient in terms of providing customers with the expected value. To say more, the company may not be able to compete with its competitors. Although it is not the only valid condition and it may not guarantee $100 \%$ success, in such a case one shall determine all the 
possible variants for future existence and operation that derive from market environment and changes being observed [Stabryla 2000] as well as establish a proper form of cooperation.

As the consequence of proposed analyses described above, manufacturing strategy can be formulated which not only supplements in more detailed manner the overall corporate strategy, but also provides a blueprint for developing manufacturing system. This long-term development plan shall have an individual character and ought to be based on products' characteristics that are planned to be launched.

The reflection of the strategy can be found in the design of the market-oriented manufacturing system and cooperation conception. The design must be validated and verified by means of simulation tool. It has to be modeled in a way that reflects system's structure and designated business processes. The way the system is organized has to be modeled too. The analyses' outcome provides necessary information that are further used in the detailed design of the structure and infrastructure of the manufacturing system. Chosen information can also be used to develop an implementation plan. Since new manufacturing system must be fully integrated with other company's functions, an integration blueprint has to be developed too.

The way the new manufacturing concept will be implemented is strongly dependant on the quality of implementation plans. Although the overall success is strongly related to the skills of people being in charge of implementation processes, barriers, trade-offs, bottlenecks, boundary conditions, and constraints must be identified and deeply analysed. Thus, thorough investigation must be performed and every critical aspect considered before the design takes place and implementation blueprint is developed. Apart from economical, bearuocratical, and sociological issues that need to be taken into account, special care shall be taken when considering what is missing in the area of information technology support for each of collaborating partners.

Literature studies as well as industry practices prove that there is a need for dedicated IT solution that would integrate company's operational and strategic management levels. In the research project that is being described, authors suggest the proposal that includes the following innovative elements: the use of methodology dedicated to specify manufacturing strategy based on the information acquired from identified customer needs and stated company's strategic goals; the transformation of manufacturing strategy into the design of manufacturing system which performance is to measured against assumed production strategy.

The system that is being worked out can be applied by the companies producing and selling wide range of diversified products, but also batch-manufacturers and jobshop operators competing in unstable market environment. System's objective is to help the companies boosting their competitiveness. It will be applicable to both new and existing manufacturing companies.

The module for determination of cooperation range is decision making module and is responsible for processing input data and support decision regarding choice of form of cooperation. The input data, coming from the phase of strategic analysis, are trend of demand as well as range/changeability of products. The data will be processed using Manufacturing Strategy Deployment (MSD) method which was 
developed at Centre for Advanced Manufacturing Technology. The MSD tool serves for support and implementation of strategic oriented and coherent decisions regarding manufacturing. The tool was developed using Quality Function Deployment (QFD) methodology. MSD enables translation of key requirements and expectations of customers into goals that are agreed to realize within a design project of a market-oriented manufacturing system. To collect results of MSD analysis, a form based on QFD is used. The form was modified, but it was necessary for the reason of different application. The correct application of the tool requires to obey determined procedures.

Application of MSD enables determination of goals for implementation in the process of manufacturing system design as well as of goals for further realization during the phase of preparation for manufacturing system implementation. Based on MSD tool requirements regarding hypothetical manufacturing system will be determined. From the other side data coming from manufacturing system monitoring module will say about abilities of the current manufacturing system.Based on the data the user should decide whether design a new manufacturing system or leave it as it is or to determine form of cooperation, which will meet the requirements better along the cooperation forms shown on Figure 1.

\section{Functions and structure of system for strategic manufacturing}

The system that is in the phase of development has a modular structure that has been presented on Figure 5.

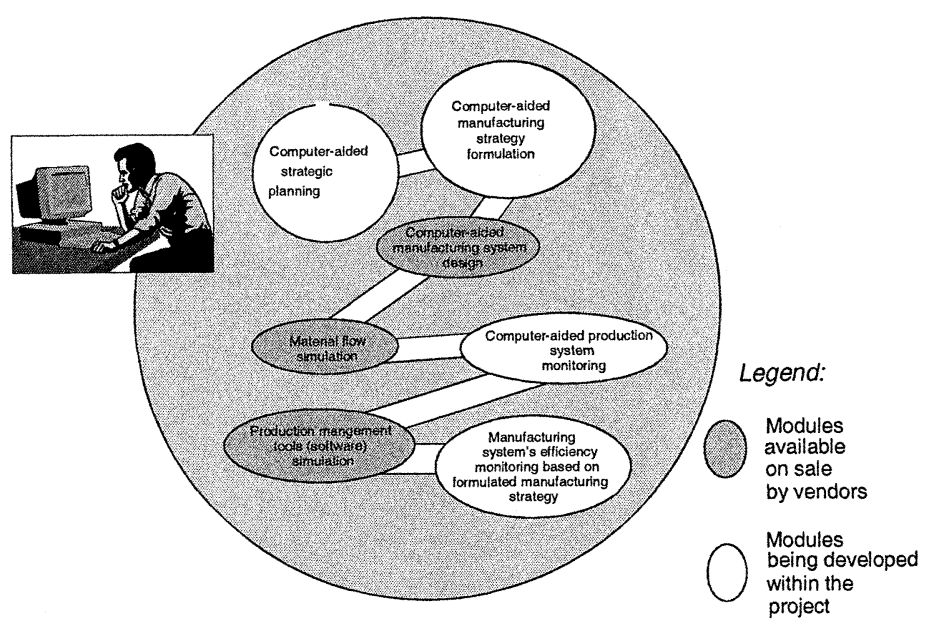

Figure 5 - System for Strategic Manufacturing

Some of presented modules are of commercial origin and are available on sale whereas the rest has been subject to on-going research investigations. One of the key issues being considered is a specification of data interchange between the modules. Proper definition of interfaces within the System for Strategic Manufacturing is a prerequisite for successful system development and application. On the Figure there 
have been also presented in a schematic mode links between all the modules. These links represent interfaces (or data exchanged) between the system's modules. The system is being worked out on the Windows platform. As a tool for simulation purposes Arena software is being used. Arena works with Visual Basic environment by means of its internal interface. MS Access has been chosen as database software tool.

Figure 6 shows the refined structure of data flow within the system. A global company's strategy expresses long-term goals that correspond to the company's overall business conditions. These can be determined on the basis of the analysis of internal and external factors influencing the business. Global strategy also presents the allocation of resources that are necessary for the execution of stated goals. General strategy is then disaggregated onto functional levels like manufacturing, marketing, distribution etc.

On the basis of general strategy, one can work out the marketing concept. Company's environment monitoring provides the necessary information on market requirements. Gathered information on competitors, trends in manufacturing, new technologies etc. can be used to quantify company's internal capabilities and to propose relevant changes. Based on market requirements', research results, and quantified company's capabilities, relevant market segments and products can be defined. This kind of information can be then used in manufacturing strategy analysis.

Manufacturing strategy analysis requires, in addition, an input laid by general strategy's implications. Product portfolio and products' characteristics, as well as market requirements and characteristics, determine what appropriate manufacturingrelated decisions must be taken. This aims at obtaining the requirements for the manufacturing system. It is proposed that MSD method is used for transforming market and product requirements into manufacturing system requirements.

Manufacturing strategy formulation shall begin with determining characteristics and necessary parameters of the manufacturing system. Based on this data, one can choose the most relevant manufacturing system and proceed with layout modelling. This shall take into account the issues of integration with other functional areas related to manufacturing. Once the model is completed, simulation shall be applied so that the discrepancies can be discovered, and necessary modifications handled. After simulation, implementation plans and steps should be realized. Strategy formulation can be then regarded as finished.

Transformed manufacturing system shall always be monitored by the set of metrics established in the manufacturing system project phase. Obtained data shall always be analyzed against figures stated in the project and feedback shall be used for necessary corrective actions. 


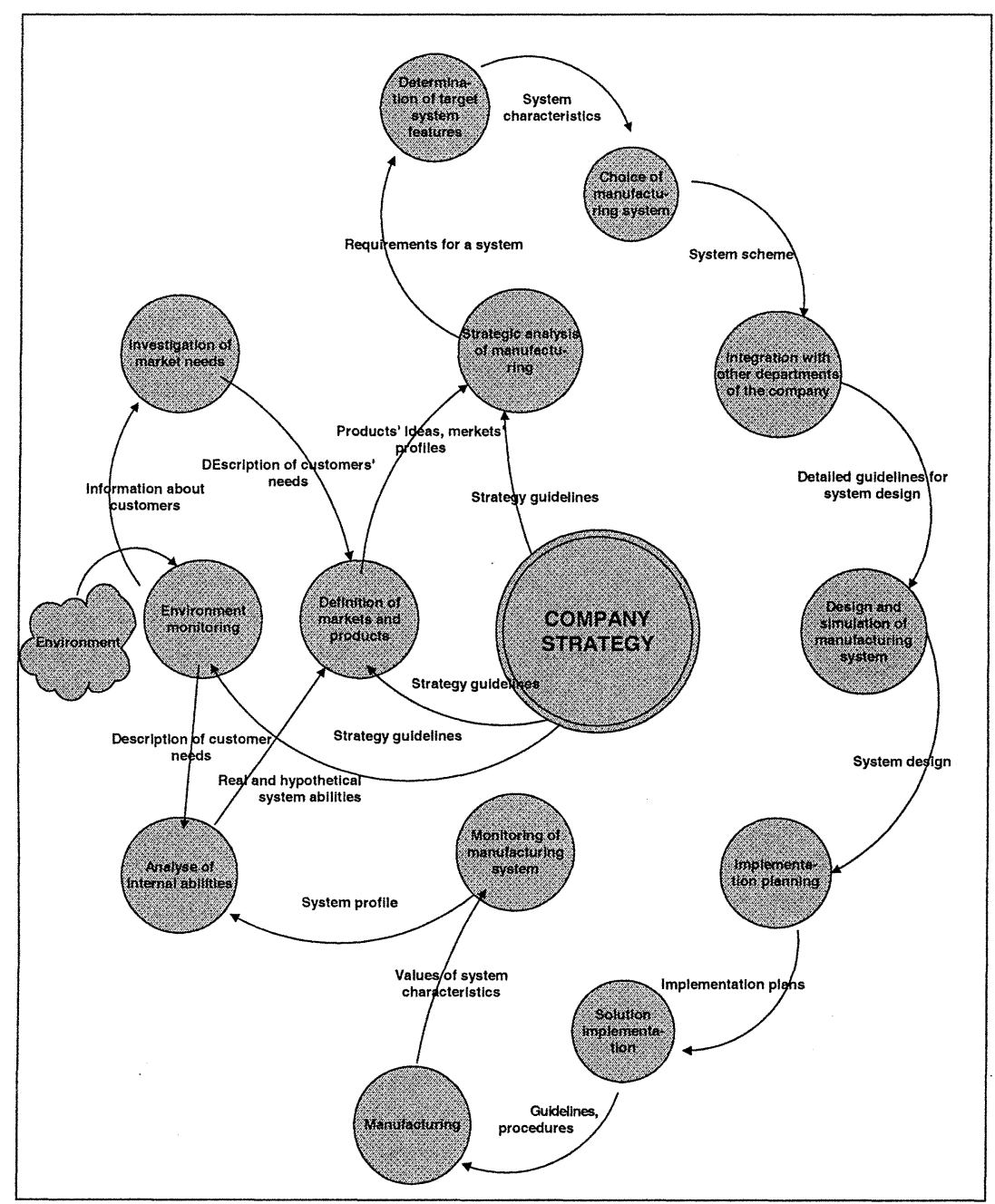

Figure 6 - Data flow diagram in the system

\section{REFERENCES}

[1] Cygler J.: Alianse Strategiczne, Diffin, Warszawa 2002.

[2] Moszkowicz M.: Ewolucyjnosc i wirtualnosc w zarzadzaniu strategicznym, Nowe kierunki w zarzadzaniu przedsiebiorstwem - koncepcje przekrojowe, PN nr 784 , Wroclaw 1998.

[3] Strategor,: Zarzadzanie firma, strategie, struktury, decyzje, tozsamosc, PWE, Warszawa 1995.

[4.] Christopher Martin,: Logistics and Supply Chain Management, Wydawnictwo Profesjonalnej Szkoly Biznesu, 1992.

[5] Stabryla A.: Zarzadzanie Strategiczne $w$ teorii i praktyce firmy, Wydawnictwo Naukowe PWN, Warszawa - Krakow 2000. 
[6] Gilgeous V.: Gilgeous M.: A framework for manufacturing excellence, Integrated Manufacturing Systems 10/1 [1999] 33-44, (C MCB University Press, 1999.

[7] Kaplan R.S., Norton D.P.: Strategiczna Karta Wynikow, Wydawnictwo Naukowe PWN, Warszawa 2001. 